\title{
身体名詞構文における所有表現
}

1. 序

現代スペイン語の所有形容詞弱勢形（本稿ては強勢形は扱わないのて, 以下 「所有詞」と略) は限定辞の一つとして認められ 詞を具現化する機能を持つ。

しかし，身体部分を表わす名詞を目的語などにとる構文，いわゆる身体名詞 構文ては, 身体部分の所有者の特定が文脈その他の方法てでるならば，身体 名詞の限定辞は所有詞てはなく，定冠詞てあるととが多い2）。ただし（1)の身 体名詞の所有者が Eva であるとい5直観的な判断は, 常識的な文脈の想定飞基 うくすのてあり, 定冠詞が所有者を表示する訳てはない゙）。

(1) Eva agitó las manos.

また, 再帰動詞を伴ら身体名詞構文ては, 身体名詞の所有者は文の主語てあ るという解釉しかあり得ない。

(2) Miguel se lavó la cara.

(1)，(2)のよ5な文は主語以外の人物の存在が統語的に明示されていないのて, 主語が身体名詞の所有者てあると判断しやすい。しかし, 主語以外の人物す明 示された(3)は，(1)や(2)上りす身体名詞の所有者の特定がしにくい筈なのに, 所 有詞を用いていない。

(3) Montoya me puso la mano sobre el hombro.

通常の文脈では, la manoは Montoya, el hombroは「私」のすのと解粎 される $3^{4)}$ 。とてろて, 与格人称代名詞は身体名詞の所有者表示方法の一つてあ るが, (3)の「私」は la manoの所有者とは考えにくい 5 )。との上 はむしろ文脈によって特定されるととがある。 
主語と主語以外の人物が明示的な構文で, 所有詞を使わずに所有者の特定が てをるといらととは, 文の意味解釈に関与する要素の存在を想定させるが，そ れはどのよらなるのだろらか。また, 所有詞以外の, 所有者表示方法と看做さ れる手段は，実際どの程度まて所有者特定に関与するのだろらか。

スペイン語が所有詞を比較的使わない言語であることは，Wandruszka (1976：309-321) の六力国語対照研究6)て子明白てある。スペイン語と英語 の所有詞使用の度合いは特に上く比較されるが, 本稿ては, 言語対照上りるス ベン語自体の特として，身体名詞構文の所有者表示をめぐる問題と所有詞 使用（或いは不使用）傾向について考察する。特に, 主語と主語以外の人物に 言及する文を多く取りあげたい。

2. 身体名詞構文の所有者表示方法

身体名詞構文の所有者表示方法は六種類ある。

I. 所有詞

(4) Gabriel levanta su mano.

II. de +名詞

(5) Gabriel levanta la mano de Eva.

I. 文眽や言語外の状況に上る意味解㸽

(6) Gabriel levanta la mano.

IV . 再帰代名詞

(7) Eugenio se lava la cara.

V. 与格人称代名詞

(8) Clara me limpia las uñas.

VI. 対格人称代名詞

(9) Sergio la agarró del brazo.

(4)の所有詞 su は, 主語と同一指示の時, 余剩表現と看做されるのて, (6)の 上5反定冠詞を使い, 所有詞の特定を文脈や言語外の状況に依存するのが普通 てある。 su が同一指示てない時は，その内容が(4)の表現ては分かりにくいの 
て,むしろ(5)の上5K「de十名詞」の表現形式を用いる。すをわち、I.上り もII.คI.が好まれるのてある。

I.は他の統語的表示方法とは異なり，語用論的左表示方法とてい呼ぶべ 性質を持っている。てのI.の潘か，IV.〜VI.の代名詞を用いる時，身体名詞 につく限定詞は定冠詞てある。

主語てない人物が与格または対格て表示される文における身体名詞の所有者 の特定については，第3・4章てそれぞれ詳しく見ていくことにする。

なお，本稿ては身体名詞構文の主語として人間を想定しているが7)、スべ ン語には身体名詞を文法上の主語とする構文すある。

(10) Le tiemblan las piernas.

所有者表示方法としては，（10）はV.のタイプに属する。しかし，ての粠文 ては，与格て表示される人間とは別の人間が明示されていないのて，その上ら 左人間の存在は，特殊支文眽を考えない限り，極好想定されにくい 8 。そ己 が人間を主語に持つV.のタイブの身体名詞桡文とは異なる点てある。

本稿の意図は，身体名詞飞関わる人間がとんな方法て表示されるか，またそ の表示が身体名詞の所有者を確実に伝えるかどか子追究する点にあるのて， I.〜VI.の分類て処理しきれない（10）の上5な粠文は扱わない。

3. 与格人称代名詞を伴5身体名詞構文

スペイン語の，主語と主語以外の人物に言及する身体名詞構文ては，主語以 外の人物が与格人称代名詞て表示されるととが多い。

(11) Alfredo le limpio los dientes.

（11）ては，与格人称代名詞が身体名詞の所有者を表わす。（11）のleを再

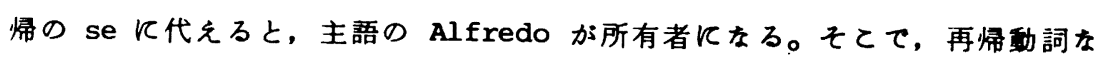
ら主格が所有者,「与格人称代名詞十他動詞」去ら与格が所有者を表わす, と 結論つけたいとてろてあるが，所有詞について二通りの解粎が可能な文がある。

(12) Gerardo me levantó la mano.9)

(1) Gerardoは私の手をあけた。 
(2) Gerardo は私に向かって（彼の）手をあげた。（なぐった，挨拶した の意味て）

また，主語が身体名詞の所有者であるといら解釈しか許さない構文すある。

(13) E1 profesor me fruncio las cejas.

(11)－（13）は統語構造が同じのに，身体名詞の所有者が異なるのはなぜ だろらか。

問題を解く键は動詞にありそ5だ。（11）の動詞 limpiarを再㛿動詞 limpiarse K代えると, 動詞の動作が向から方向が変わる。

(14) a. Alfredo le limpió los dientes.

b. Alfredo se limpió los dientes.

歯の所有者は (14 a ) ては, le，（14b)ては Alfredoてある。

一方, (12)の levantar, (13) の fruncir は各々再㛿動詞 levantarse, fruncirse とは代えられない。

(15) a. Gerardo me levantó la mano.

b. * Gerardo se levantó la mano. 10)

(16) a. El profesor me frunció las cejas.

b. *El profesor se fruncio las cejas.

（15 b ）の levantarse は身体全部に関する動詞なのて, 身体の一部に言及

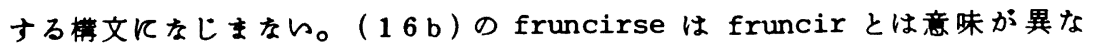
る。

このよらに(11)と（12），（13） は再㷌代名詞に関して異なる特性を持つ。 身体名詞楼文中の再㷌代名詞につんては官本 (1984)の研究が詳しいのて，こ れと関連うけて三種類の構文を検討してみ上5。

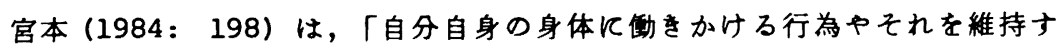
る状態を表現する棬文て，その身体名詞を目的語とする構文」として，1）他 動詞十身体名詞 2) 再煗代名詞+他功詞＋身体名詞の二種を挙げ, 詳しく解 説している ${ }^{11)}$ 。そして 1)の棒文をとる功詞を《levantar》類，2）の橉文を とろ動詞を《lavarse》類と呼占。 
（11）の動詞は言わば《lavarse》類の一つであり，(12)（13）の動詞一 levantar と fruncir — 《levantar» 類である。

宮本（1984：217-218)の結論ては, 再㷌代名詞の存在は主語の身体への 「接触」及び「運動方向性」を表わし，再㷌代名詞がない場合はその上らな 「接触」・「運動方向性」が久如しているとい5。(14 b) の limpiarse は 主語への「方向性」を持つ再㷌代名詞を伴ら動詞なのて,（14 a ）の上5 亿再 帰代名詞以外の代名詞が用らられると, 主語てはない, その代名詞が指示する 人物の方に動作が向からのかるしれない。（１４ａ）と（１４４ｂ）の身体名詞の所 有者が異なるのは, 再㷌代名詞の有無に依ると考えられる。

一方，主語の動作を表わす《levantar》類の動詞は再帰代名詞を伴わない のて，動作の「方向性」を明示するすのは何すない。との種の動詞を用いる構 文における所有者の特定は, 文眽や言語外の状況に依存する。全般的には, ( 16 a ) の上5に主語が身体名詞の所有者でるととが多い上うだ。第 1 章て 引用した（3）の動詞も，宮本（1984）では挙げられていないが，《levantar》 類に属するのて, 主語が直接目的語の身体名詞の所有者と解釈されるのが普通 てある。そして，とのよう左解釈が行われるのは，Roldån (1972：28-29) が指摘するよ5に，ての種の動詞が "voluntary action" を表わすととと関 連があると思われる。

しかし, 文脈に依る判断は，時に（15 a ）の上らな両義文を生み出す。それ が主語の意図的な行為を表わす文と解釈されれば, 主語が所有者と考えられる が，与格て表示される人物に意図的に何かをさせるといら解釈ならば，与格の 人物が所有者と判断される。両義文を生み出す動詞は，Roldån (1972)の例 ては, levantarの他, cerrar, mover である。管見では, 《levantar》 類の動詞で両義文を生み出す動詞はあまり多くなさそらだ。

以上の上うに，宮本（1984）が分類した se の有無に関する二種類の動詞は; 「接触の有無」・「運動の方向性」のみならず, 身体名詞の所有者の表わし方 も異なっている。

ととろて, Real Academia Española (1973：207) は身体名詞構文に使 
われる与格人称代名詞を dativo posesivo と呼ふ。本稿て対象外とした (10) の上5な文につんては確かにそら言えるが，人間が主語になる身体名詞構文て は，既に見たよ5に「与格＝所有者」と言い切れない。Strozer（1978： 120-121)によると, 与格人称代名詞の規定・名称に関する諸家の意見は様々 てあるが, 結局どの与格す何らかの利害や関与を示す。従って, (11)-(13) の与格は dativo de interésと考えるのがよいと思われる。人間を主語にと る身体名詞構文ては，与格の人間が動詞の表現する動作によって受ける影㫼は， 心理的と言ら上りむしろ物理的性質のるのであ。しかし、影皘を受けるとと と身体名詞の所有者かとらかといらこととは別問題である。Costa olid (1981：92) が言5よ5に, dativo de interés は身体名詞が詿已関係持 つのかを示すのみである。

4. 対格人称代名詞を伴5身体名詞構文

身体名詞の所有者は对格人称代名詞に上ってる表示される。

(17) Juan la cogió del brazo.

身体名詞が伴ら限定辞は定冠詞て，対格て表示される人物が必ず身体名詞の 所有者てある。

このタイブの構文は限定されている。動詞は agarrar, coger，tomarなど， 相手飞何かを件をかける動作動詞である。身体名詞が伴 5 前膡詞もa，de， porなどに限られ，動作の向から方向や拠点を示す。

この前置詞の存在は，関係文法の見地飞基ゔ説明される ${ }^{12)}$ 。(17)はJuan

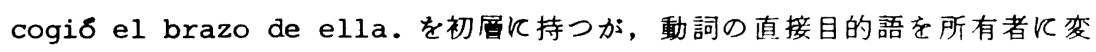
える「所有者年格」(possessor promotion) ${ }^{13)}$ にって, 初層の直接目的語 のらち, 身体名詞が失業者」(chômeur) になる。つまり, el brazoは初首 における文法関係を終首ては失ん，それを示す標識として de が付与される。

身体名詞構文の統語論を分析した Hyman (1977)によると，類型論的に見て， 「所有者界格」といら統語現象を持つ言語は数多い。所有者は直接目的語また は間接目的語に㫒格するが，とちららの目的語に年格するかは言語によって異な 
り, 例えば, バントゥ一諸語の一つ, Haya 語ては, 所有者は直接目的語に䄯 格する ${ }^{14)}$ 。従って, 身体名詞の所有者を与格て表わす傾向は, スペイン語とん ら言語の特徽の一つてあると言える。

スペイン語て対格人称代名詞をとる動詞の種類は限られるが,てれらの動詞 は対格人称代名詞だけてなく，与格人称代名詞とす共起する。

(18) El niño la agarra por la nariz.

(19) El niño le agarra la nariz.

三名の母国語話者に二つの文の意味の連いを非ねたととろ（18)は「捸む」 ことて, (19) は優しく掊てる感じとい5回答が得られた。しかし, 味は変 わらないと答えた人るんたのて，意味の逜いはあまり際立ったすのてはないの かるしれない。

しかし, 対格人称代名詞の使用は, ある一点に狙らを定めて強く動をかける というニュアンスを出す。この時, 身体名詞は強い㗢きかけの㷌着点として, 点的に捉えられている。

このよらな構文の性質を考えると, 身体名詞の所有者は, 主語てはなく対格 人称代名詞て表わされる人物としか解躯てをないのは当然てある。

Hyman (1977：104）飞よると, 「所有者㫒格」は所有者が動詞の動作に 物理的影繁を受ける時に起こる。例えば, 他人の腕を引っばるととはその人の 身体全部に影䇾を及注す（転がとか，悲鳴を上げるとか）ととになる。

スペン語の場合, 与格て表示される人物す多少の物理的影整を受ける。し かし, 対格て表示される人物が受ける物理的影整は, 上り直接的かつ部分的て あるととが, このタイブの構文の表わす意味内容からる察せられる。

\section{5. 所有詞使用をめぐって}

てれまて所有詞不使用の例ばかり挙げてをたが, 今度は所有詞が使用される のはどんな場合かを検討してみよう。

(20) ??Ana se lavó su cara. (su=de Ana) ${ }^{15)}$

（20）は余剩表現て, 通常使用されないが, 特別に所有を強調したり, 皮肉 
て言ったりする場合のみ認められる。

Costa Olid（1981：93）は，文脈に依る文の意味解釈が所有者と所有さ れるすのの関係を確立するとは限らないととに着目する。そして, 所有詞使用 が, 逸脱した状況を明らかにし，特別なニュアンスを文に与えると述へている。 例を挙げてみ上ら。(21)ては, 普通, 手の所有者は と考える。

(21) Ana levantó la mano.

しかし，特殊な文眽を想定すると，所有者か：Ana 以外の人物といらとともあ り得る。その場合は, (22)の上5に所有詞を使らことによって, 特殊な文脈 の存在が暗示される。

(22) Ana levantó mi mano.

これも一種の強調用法かるしれないか， mi は（20)の suとは䢖って，余 剩表現てはない。

この上5に，所有者に関する情報が不十分だと思われる時に所有詞が使われ 万。

ただし，（２０）の再㛿動詞文は，主語と同一指示てない所有詞の使用を容認 しない。

(23) * María se lavó mi cara.

また, 主語が所有者とい5解粎しか許さない（13)のタイプの構文す, 主語 と同一指示てない所有詞の使用を認めない。

(24) *El profesor fruncio mis cejas.

つまり，所有詞は使用されない訳てはないか，（21）の上5に, 所有者の特 定を全面的に文脈や言語外状況に頼る構文中に限られる。

身体名詞棬文飞限って言えば，身体部分は身体との密着度が強らととす，所 有詞不使用の一因となっている上らだ。密着度が強いと文の暧昧さが減少し， 文脈などに上る所有者の特定が容易になるのかもしれない。

では, 身体への密着度が弱い場合は, 所有詞使用の傾向が強まるだろらか。 てれまて，身体名詞として，身体部分ばかりを报ってをたが，开・涙・声なと 身体から分泌または発せられるるのる広い意味ての身体名詞と考えられる。(以 
下，「身体付随物」と総称する）また，身体名詞てはないが，人間の所有物， 特に，帽子・手袋など身につけるるのる身体に所属する物と考えられる。（以 下,「所属物」と総称する)

身体部分を表わす名詞や「身体付随物」を表わす名詞の所有は，いわゆる 「誶渡不可能所有」（inalienable possession）であり，「所属物」を表わ す名詞の所有は「譲渡可能所有」(alienable possession)である。

以上, 三種類の名詞を「身体関連名詞」と総称するが, これらの名詞は身体 への密着度が異なる。特に, 譲渡可能な「所属物」の所有者の特定は, 譲渡不 可能な他の身体関連名詞の所有者の特定上り難しいのて, 所有詞に上る所有者 表示とい5方法が採られる余地がありそらだ。例えば，（25）の再帰代名詞は 所有者を表示していない。

(25) Manuel se puso mis zapatos.

これは, 所有者に関する情報が不十分だと思われる場合の所有詞使用の一例 てある。

変渡不可能な他の身体関連名詞てる同様の例文を作ると, 非文法的な文がて きる。

(26) * Isabel se lavó mi cara.

(27) * Marla se enjugó mi sudor.

こらして, 譲渡可能な「所属物」の所有者は, 特別な強調のニュアンスなし 飞所有詞て表わすととが可能であるとわかる。

それては，譲渡不可能な身体名詞と「身体付随物」名詞とては，所有詞との 相性に差があるだろらか。このてとを確かめるために，宮本（1984：203）て， 《lavarse》類の se が省かれた時, 身体名詞が伴ら定冠詞を所有詞に代える と, 文の容認性が上がるととを確認するために用いた方法（28）を借りる ${ }^{16) 。}$

(28) a. Juan se limpio las uñas.

b. * Juan limpiઠ las uñas.

c. Juan limpio sus uñas.

「身体付随物」名詞ても同様のテストをしてみた ${ }^{17)}$ 。 
(29) a. Pedro se tomó el pulso.

b. ? Pedro tomó el pulso.

c.?? Pedro tomó su pulso.

( $29 \mathrm{~b})$ は自分以外の誰かの眽をとると解釈され，(29c）はやはり se が 必要と母国語話者の回答があった。「身体付随物」の所有者は所有詞て表わし にくいととがわかった。

以上を要約すると，身体名詞構文中の再㷌代名詞の代わりに，所有詞を用い ても文意を損ねない名詞を順に挙げると，

(1)身体への「所属物」を表わす名詞

(2) 身体部分を表わす名詞

(3)「身体付随物」を表わす名詞

である。とれは，所有詞を伴いやすい名詞の順序とる言える。

「身体付随物」は身体部分上りる身体への密着度が弱そらなのに，その名詞 は所有詞を最る必要としないといら結論に至った。これは，开・血・脈など固 体には程遠くて実体の捉えにくらものに，所有詞がじまないととに㷌因する のではないかと思われる。

\section{6. 結 論}

これまて、スペイン語の身体名詞構文，特に主語の人物と主語てない人物に 言及する構文における身体名詞の所有者を表わす様々な方法を概観したが，乙 の構文ての所有詞不使用の傾向は著しい。所有詞の代わりに定冠詞が身体名詞 の限定辞となり，所有者表示の役割は代名詞類が担らことが多いが，てれらの 統語的手段は必ずしす所有者を表わすとは言えない。

与格人称代名詞を用いる身体名詞構文の所有者は, 構文中の動詞の種類に上 って判断される。実質的には，与格人称代名詞は所有者表示機能を持っていな らと言える。対格人称代名詞を用いる場合は，所有者は対格て表示されるが， スペン語ではこのタブの構文は限られている。

所有詞が使用されるのは，所有を強調する時と所有者に関する情報が不十分 
な時てある。

身体関連名詞の所有詞の伴いゃすさは, 身体との密着度の強弱上りす, 名詞 の形状に左右される。「所属物」が所有詞を伴いやすいのは, 譲渡可能てある といらだけてなく，固体に最す近いからと言える。「身体付随物」は形状が定 めにくらのて, 所有詞と共起しがたいのである。

また，身体関連名詞の所有詞の伴いやすさを調へるにあたり，再㷌代名詞も 常に所有者を表示するとは限らないてとがわかった。

ての上5に，統語的手段に上る所有者表示は絶対的なるのてはないが，文脈 や言語外の状況なと，語用論的手段にす依存して所有者をつをとめるのて，ス ペイン語は，少なくとす身体名詞構文に関して，所有詞を用いない傾向の強い 言語の一つと認められる。

注

0) 本稿は 1988 年 7 月 28 日, 第 8 回スペイン語学研究会夏期セミナー（於 玉川学園須雲塾）における研究発表「限定詞としての所有詞の位置付け」の 一部を修正・増補したすのてす。御意見を賜わった先生方に御礼申し上げを す。

1) Contreras (1968) は所有詞を限定詞として認めない。また, 古い時代に, 或いは現代てい一部方言で, el mi libroのよ5な表現がある。しかし， 現在数多くの文法書がそらしている上らに、筆者す，現代スペイン語ては所 有詞を限定辞の一つと認めるという説を採る。

2) 不定冠詞の使用すあり得るし, 無冠詞の場合するるしかし, 佐藤 (1973) に上ると, 不定冠詞, 無冠詞が選択される場合は, 所有者に関心が払われて レない。(“1”といら数表象の意識，紹介導入など）所有関係を問題に する本樀ては, 不定冠詞, 無冠詞を考虑外とする。

3) Hernández Alonso（1984：451）に上ると, 冠詞の価値は基本的に deIctico で, 文脈から「所有」とい5 二次的価值が生まれる。なお, Radelli (1978：235）が指摘するよ5に, 所有詞も常に「所有・所属」を 
表わす訳てはない。

4)（3）は Wandruszka (1976：319）の例文である。Wandruszka は，身体 名詞の所有者が, 特殊な文脈ては, 通常の解釈とは異なることを示唆してい る。

5）「与格＝所有者」とは限らないとい5ととは，Roldán（1972：29）が既 に述へている。

6) 英語, スペイン語, トイイッ語, フランス語, イタリア語,ボルトカル語の 六カ国語の対照が行われている。

7）人間に限らナ゙, [+animado] の意味素性をるつ名詞てあればよい。ただし， 本稿の例文の主語は人間に統一してある。

8）Roldán (1972：27）によると，非常に特殊な文脈を想定すれぱ, (10) の上らな文の与格す所有者を表わさないてとがあるという。しかし，その特 殊性から考えて，（１０）の上5な文の例外报いは妥当てあると筆者は判断し た。

9) Roldán (1972: 29) の例。(2)の解釈のほらがより普通てある。

10）・は非文法的てあるてとを意味する。

11) 同論文には，再㛿代名詞十動詞十前罡詞十身体名詞す拳り゙られているが， 参考程度に取报われているにすきない。

12) Hyman (1977)，Deguchi (1979) を参照。たたし，両論文とる純粋な関 係文法の枠組みに依る。のてはない。

13) Hyman (1977) の用語。関係文法ては 'Possessor Ascension'とい5用 語を用いている。

14) Hyman (1977: 101) 参照。

15）（20）は㬰際に用いられないが, 非文法的ではないのて，??の印をつけ る。

16) 宫本（1984：203）のこの例は, 再㷌代名詞が身体部分の所有者を明示す る针をを持つてとを実証するためのるのてある。

17）母国語話者三名の方に例文の文法性を判断していたたいた。（29）の例文 
の5ち，全員に非文法的と判断された文はなかった。総合的に見て，?はや や容認しがたん，??はかなり容認しがたいととを意味する。

\section{参考文献}

Contreras, Heles (1968), "The structure of the determiner in Spanish", Linguistics 44, 22-28.

Costa Olid, Alberto (1981), El posesivo en español, Publicaciones de la Universidad de Sevilla, Sevilla.

Deguchi, Atsumi (1979), "The syntax of direct objects in Spanish", Lingüistica Hispånica 2, 45-62.

Hernández Alonso, César (1984), Gramática funcional del español, Gredos, Madrid.

Hyman, Larry M. (1977), "The syntax of body parts", Haya grammatical structure (Byarushengo, E. et al. (eds.)), Southern California Occasional Papers in Linguistics No.6, Los Angeles, 99-117.

宮本 正美 (1984)，「スペイン語における身体再帰代名詞の有無」，関西外 国語大学研究論集 40, 193-223.

Radelli, Bruna (1978), "Los posesivos en español", Nueva Revista de Filologra Hispánica 26, 235-257.

Real Academia Española (1973), Esbozo de una nueva gramática de la lengua española, Espasa-Calpe, Madrid.

Roldån, Mercedes (1972), "Concerning Spanish dative and possesives", Language Sciences 21, 27-32.

佐藤 㺵美子 (1973)，「身体の部分を表す名詞と冠詞につんて」， Hispånica $17,1-21$.

Strozer, Judith (1978), "On the so-called "dative of interest"", Hispania $61: 1,117-123$.

Wandruszka, Mario (1976), Nuestros idiomas: Comparables e incomparables, Gredos, Madrid. 
La expresión de posesión en la llamada construcción de nombres de 'partes del cuerpo'

por Terumi EZAWA

El español es una lengua en la que no se usa el posesivo relativamente. Pasa lo mismo en la llamada construcción de nombres de 'partes del cuerpo' que tiene como sujeto un ser humano y como complemento nombres de 'partes del cuerpo'.

En dicha construcción, el poseedor es expresado sintácticamente por el posesivo, la forma 'de + nombre', el reflexivo, el dativo clftico o el acusativo clitico.

También se expresa por el contexto o por una situación extralingüfstica. En muchos casos, el artfculo substituye al posesivo.

Pero todos estos medios, salvo el posesivo, no pueden expresar la manifestación del poseedor de un nombre de 'parte del cuerpo'. Por ejemplo, juzgamos el poseedor de dicho nombre en la construcción con el dativo clftico por las categorlas verbales. Por eso, no es perfecta la manera sintáctica de manifestar el poseedor, pero los medios pragmáticos la ayudan.

Usamos el posesivo cuando acentuamos la posesión o cuando creemos que no es suficiente la información sobre el poseedor. Además, las categorlas de nombres de 'partes del cuerpo' influyen en el uso o desuso del posesivo.

En general, la materia que no tiene forma concreta, como sudor o sangre, no comparte tanto con el posesivo, y las pertenencias del hombre (zapatos, sombrero, etc.) pueden compartir fácilmente con el posesivo, por su forma concreta más bien que por su alienabilidad. 